\title{
Nauczanie przez sztukę jako metoda wychowawcza i terapeutyczna dzieci zdrowych oraz dotkniętych niepełnosprawnością intelektualną
}

Teaching by art as educational and therapeutic method for healthy and afflicted by intellectual disability children

\section{Streszczenie:}

Niniejszy artykuł dotyczy pojęcia twórczości w odniesieniu do osób niepełnosprawnych intelektualnie. Wraz ze wzrostem zainteresowania różnorodnymi metodami edukacyjnymi pojawiło się sporo możliwości. Wiele z nich odnosiło się do aktywnego wychowania w relacji ze sztuką i przez nią. Przekonanie, że styczność z twórczością artystyczną i zachęcanie dziecka do aktywnego kontaktu z nią stanowi główne założenie pracy. Dodatkowo, warto zaznaczyć, że zachęcanie dzieci do niecodziennych rozwiązań i wyrażania ich przez prace plastyczne przynosi korzystne skutki w ich późniejszym życiu. Ważne jest to tym bardziej w kontekście dzieci i osób dorosłych niepełnosprawnych intelektualnie. Poniższy tekst jest jedynie zarysem problematyki i kilku wybranych zagadnień teoretycznych z obszaru wychowania przez sztukę..

Słowa kluczowe: wychowanie przez sztukę, arteterapia, twórczość, niepełnosprawność intelektualna 
Wiktoria Kabat - Nauczanie przez sztukę...

\begin{abstract}
:
This article refers to the idea of creativity in reference to people with intellectual disabilities. With the growing interest in a variety of educational methods there appeared many opportunities for the active education in relation with art and through it. The belief that contact with artistic creativity and encouragement child to similar activities are important factors in its development, is the main topic of this work. In addition, it is worth noting that encouraging children to unusual solutions and expressing them through art works is beneficial in their further life. It is of a great importance, especially regarding children and adults with intellectual disabilities. The following is only an outline of the issue and of a few selected theoretical problems in this area.
\end{abstract}

Keywords: art therapy, creativity, education, mental subnormality

\title{
Wstęp
}

Jako krytyk sztuki często zauważam, że wielu ludzi - laików obserwatorów jest sceptycznie nastawiona do wątków związanych z twórczością artystyczną. Spotykam się z komentarzami typu „nie wiem o co chodzi”, „to nawet nie jest ładne”, „nic nie wyraża”. Ludzie wycofują się, gdy stykają się z czymś, czego wcześniej nie znali. Współczesne możliwości stwarzają wiele opcji działań dla artystów, które często nie są zrozumiałe dla przeciętego widza. W sztuce najpiękniejsze jest właśnie to, że „nie ma rozwiązań jedynie słusznych, powodzenie jest zagwarantowane"1, więc nie trzeba bać się kontaktu $\mathrm{z}$ nią.

W tym artykule kieruję się myślą Tatarkiewicza, że „sztuka jest odtworzeniem rzeczy bądź konstruowaniem form, bądź wyrażeniem przeżyć - jeśli wytwór tego odtworzenia, konstruowania, wyrażania

1 G. Szafraniec (red.), Kultura a integracja - sztuka wobec niepełnosprawności, Katowice 2003, s. 47. 
jest zdolny zachwycać bądź wzruszać, bądź wstrząsać"2. Uważam, że sztuka spełnia swoją rolę, gdy wpływa na nas, na nasze odczucia, nakłania do dyskusji, wywołuje poruszenie. Kiedy po wystawie myślę o dziele przez kilka dni i wracam do niego - artysta spełnił swoją rolę. To samo można odnieść do postaci artysty, zwłaszcza niepełnosprawnego intelektualnie: jeśli udało mu się wyzwolić swoje uczucia dzięki działaniom twórczym to oznacza, że zadanie sztuki zostało wypełnione. Realizacja jest możliwa przy współistnieniu kilku czynników, które opiszę w poniższym tekście.

Magdalena Abakanowicz, rzeźbiarka, we wprowadzeniu do drugiej części „Arteterapii” mówi, że „Sztuka nie rozwiązuje problemów, lecz uświadamia nam ich istnienie"3. Podążając za tym stwierdzeniem warto przyjąć tezę, że sztuka daje możliwość wyrażania siebie, swoich pasji i emocji. W mniej lub bardziej świadomy sposób, z jej podpowiedzią, można przepracować nieznośne, tłumione odczucia lub dręczące nas problemy.

\section{Wpływ sztuki na człowieka - krótki rys historyczny}

Wczesne przykłady posługiwania się sztuką są widoczne już w prehistorycznych rysunkach naskalnych, które przedstawiały między innymi dzikie zwierzęta czy sceny walk. Można przyjąć, że malarstwo jaskiniowe było dla ludzi żyjących w tamtym okresie formą radzenia sobie ze strachem. Prawdopodobnie było także przejawem kreatywnej koncepcji, wczesną potrzebą wyrażenia w taki sposób zadowolenia po udanej walce czy zaznaczenie dominacji. W kontekście terapii przez sztukę wymienia się różnorodne magiczne rytuały, które miały znaczenie leczniczego obrzędu. W wielu zakątkach świata do dziś propaguje się podobne działania. Zawierały one elementy tańca, śpiewu, gry na instrumentach. Także starożytni doceniali oczyszczający

\footnotetext{
2 W. Tatarkiewicz, Definicja sztuki, [w:] P. Skubiszewski (red.), Wstęp do historii sztuki, Warszawa 1973, s. 120.

3 B. Łoza, A. Chmielnicka-Plaskota (red.), Arteterapia, cz. 1, Warszawa 2014, s. 13.
} 
Wiktoria Kabat - Nauczanie przez sztukę...

duszę wpływ twórczości artystycznej - słynne katharsis Arystotelesa to nic innego jak uwalnianie ciała z ludzkich podniet dzięki styczności z wybitnymi dziełami. Sztuka uwrażliwia na piękno otoczenia, świata.

Profesor Irena Wojnar dodaje, że obcowanie z twórczością artystyczną sprzyja pełniejszemu zrozumieniu siebie samego i pomaga w komunikacji4. Kanwą tych założeń jest nurt edukacyjny nazywany pedagogiką kultury, który posiłkuje się myślą, że kultura spełnia potrzeby ludzkie, przyczyniając się do osiągnięcia pełnej samorealizacji ${ }^{5}$. Autorzy teorii byli przekonani, że dziecko, które ma stały kontakt z kulturą rozwija się lepiej od rówieśników, którzy nie mają podobnej sposobności. Dzięki temu może tworzyć nowe wartości ${ }^{6}$. Wspomniany teoretyk sztuki, Herbert Read uważał też, że twórczość artystyczna to forma, która funkcjonuje wszędzie wokół nas, lecz rzadko się nad nią pochylamy, zastanawiamy. Jednak, warto zaznaczyć, że obecnie nie każdy przejaw sztuki będzie wywierał pozytywny wpływ na dziecko. XXI wiek charakteryzuje się wizualnym chaosem ${ }^{7}$, naładowaniem wszystkiego. Zwrócił na to uwagę Welsch, według którego współczesny świat wychowuje estetyzująco, co nie oznacza, że estetycznie ${ }^{8}$. Trzeba mieć do tematu zdroworozsądkowe podejście i pokazywać dzieciom dorobek historii sztuki oraz tłumaczyć jaka jest funkcja, przykładowo, reklam.

W XX wieku zaczęto głębiej analizować i interesować się także rysunkiem dziecięcym. Termin „sztuka dziecka” wprowadził C. Ricci w 1887 roku, tytułując w ten sposób swoją monografię na ten temat ${ }^{9}$. Istnieją dwa podejścia do tematu. Pierwszy kierunek dotyczy rozwoju twórczości plastycznej dziecka, co stało się pomocne przy tworzeniu programów, które dotyczą nauczania plastyki w szkole. Dzięki pogłę-

${ }^{4}$ I. Wojnar, Estetyka i wychowanie, Warszawa 1970.

${ }^{5}$ H. Read, Wychowanie przez sztukę, Wrocław 1976.

${ }^{6}$ Z. Kwieciński, B. Śliwerski (red.), Podręcznik pedagogiczny, Warszawa 2006.

${ }^{7}$ M. A. Karczmarzyk, Co znaczq rysunki dziecięce?, Gdańsk 2014, s. 62.

8 W. Welsch, Estetyka poza estetyką. O nowa postać estetyki, Kraków 1995, s. 35.

9 M. Lizęga, Rysunki dziecięce w kontekście powstawania wytworu, [w:] Z. Tarkowski, G. Jarzębowska (red.), Człowiek wobec ograniczeń: niepełnosprawność, komunikowanie, diagnoza, terapia, Lublin 2002, s. 257. 
bianiu wiedzy na temat rangi edukacyjnej i rozwojowej działań plastycznych dzieci, zdano sobie sprawę z wartości tego przedmiotu. Mowa też o wychowaniu plastycznym, przez które przekazuje się wiedzę o kodach wizualnych ${ }^{10}$. Za pomocą działań plastycznych buduje się komunikaty. Często jest to jedyna forma nawiązania więzów z dzieckiem niepełnosprawnym, które nie potrafi konkretnie wyrazić swoich myśli i uczuć. Coraz częściej przyjmuje się, że rysunek jest dziecięcą kulturą głosu. Dziecko może w ten sposób pokazywać, że ma coś do powiedzenia, walczy o własną emancypację.

Zwolennicy drugiej koncepcji sprawdzali za pomocą plastyki inteligencję dziecka, szukali nieprawidłowości oraz przyglądali się młodzieńczej psychice. Tutaj narodził się jej terapeutyczny wymiar, który ewoluował do formy arteterapii. Choć istnieje od lat 40. XX wieku, a w Polsce pojawiła się na dobre w latach 70.11 to pierwsze studia podyplomowe $\mathrm{z}$ tego zakresu zostały utworzone dopiero w 2001 roku na Wydziale Pedagogiczno-Artystycznym Uniwersytetu Adama Mickiewicza w Kaliszu. Wita Szulc zaznacza, że „arteterapia polega na wykorzystaniu różnych środków artystycznych, które ułatwiają pacjentowi ekspresję emocji"12. Warto zwrócić uwagę na fakt, że arteterapia pozostawia pełną dowolność, daje możliwość nieskrępowanego wyrazu artystycznego. Może to prowadzić do stworzenia niezwykłego dzieła, które jednocześnie stanie się kanwą do zmiany zachowania. Efektem końcowym tego rodzaju terapii jest pozytywna zmiana w zachowaniu i przepracowywanie problemów. Każdy wytwór jest indywidualną pracą jednostki, więc można nazywać go twórczością artystyczną, jeśli spełnia konkretne kryteria ${ }^{13}$.

10 M. Tytko, Wychowanie artystyczne dzieci i młodzieży a kultura plastyczna, [w:] A. Boguszewska, A. Mazur (red.) Wybrane problemy edukacji plastycznej dzieci i młodzieży, Lublin 2013.

${ }^{11}$ L. Hanek, Wprowadzenie do sesji na temat arteterapii, „Zeszyty Naukowe Akademii Muzycznej we Wrocławiu" 1989, Nr 48.

12 W. Szulc, Sztuka w służbie medycyny: od antyku do postmodernizmu, Poznań 2001, s. 126.

13 Piszę o nich szczegółowo w dalszej części tekstu. 
Wiktoria Kabat - Nauczanie przez sztukę...

Arteterapia nie ogranicza się jedynie do działań plastycznych, jest to szeroka metoda, obejmująca takie obszary jak plastyka, malarstwo, muzyka, rzeźba, fotografia, drama, collage, bajka, choreoterapia i inne metody pracy z tekstem lub tworzywem. Na potrzeby artykułu wyodrębniona została głównie twórczość plastyczna, jednak działać można tak naprawdę za pomocą każdej techniki.

Istnieje wiele różnych definicji arteterapii, jednak łączą je dwie rzeczy: współistnienie celu jakim jest terapia oraz metody - sztuki. Arte (pochodzi od słowa ars - sztuka) z łaciny to mistrzowskie wykonanie, a terapia kojarzy się z leczeniem ${ }^{14}$. Sprzyja nawiązywaniu nowych kontaktów i przełamywaniu swoich lęków dzięki pracy w grupie, co należy podkreślać. Doświadczenia pedagogów - praktyków nakazuje zwrócić uwagę na fakt, że w niektórych szkołach stosuje się formę działań na zasadzie spotkań terapeuty z uczniem, a bardzo ważne jest wsparcie i aktywność grupy. Wzajemne porozumienie, współpraca, nawiązywanie relacji, budowanie zaufania, to kluczowe cele jakiejkolwiek terapii grupowej. Największe różnice w opisywaniu tej kuracji wynikają z rozbieżności w rozumieniu zjawiska. W niektórych tekstach funkcjonuje jako forma psychoterapii, jako forma prorozwojowa dla ludzi zdrowych, środek wyrażania ekspresji artystycznej, jako nośnik dla edukacji kulturalnej czy metoda nakłaniająca do autorefleksji15.

Podstawą teoretyczną arteterapii są dwie teorie: emocji i twórczości. Każdy człowiek stara się przeżywać przede wszystkim emocje pozytywne, dążąc jednocześnie do ograniczania negatywnych odczuć16.

${ }^{14}$ A. Gorgól, Arteterapia w teorii i praktyce na podstawie warsztatów artystycznych dla osób niepetnosprawnych, [w:] A. Glińska-Lachowicz (red.), Arteterapia w nauce i praktyce. Teoria - rozwój- możliwości, Opole 2015, s. 29.

15 B. Łoza, A. Chmielnicka-Plaskota (red.), Arteterapia, cz. 1, Warszawa 2014, s. 13.

16 Z. Skorny, Arteterapia a zaburzenia emocjonalne, [w:] L. Hanek, M. Pasella (red.), Teoretyczne podstawy arteterapii, „Zeszyty Naukowe Akademii Muzycznej we Wrocławiu", Wrocław 1989, s. 20. 
Jedna z teorii twórczości, Anthony'ego Storry, mówi, że jest to zdolność wnoszenia czegoś nowego do ludzkiej egzystencji ${ }^{17}$.

Również lekarze donosili o pozytywnym działaniu kontaktu ze sztuką. Jeden z nich, Rosjanin, Aleksander Mudrow, powołując się na filozofie starożytne - Platona czy Cycerona - pisał, że „(...) trzeba wiedzieć, że są duchowe lekarstwa, które leczą ciało. Takim lekarstwem jest sztuka. W sztuce zawarta jest siła duchowa, która jest w stanie zwyciężyć cielesny ból, nostalgię, wewnętrzny niepokój”" ${ }^{18 .}$

\section{Wpływ sztuki na osoby niepełnosprawne intelektualnie}

Zdarza się, że impulsy ze świata do nas nie docierają. Czasami wynika to z pędu życia, przez który mijamy świat. Również ograniczenia wynikające z niepełnosprawności nie pozwalają ludziom, których dotknęły upośledzenia przyjąć wszystkich sygnałów z łatwością.

Wojciech Chudy, filozof i etyk, sam borykał się z niepełnosprawnością i mówił, że są to osoby z „brakiem”. Oznacza to brak w zakresie fizyczności, psychiki albo ducha. Ma na myśli, że człowiek to byt moralny, który czyni dobro lub zło i realizuje się w tym ujęciu ${ }^{19}$. Słabości czy nieumiejętności w sferze duchowej mogą prowadzić do niepokoju czy wewnętrznego chaosu. Należy pamiętać, że brak zdolności do dobrego rozumienia tego, co ogół ludzkości uważa za „dobro” i „zło” nie odbiera żadnej ludzkiej istocie jego człowieczeństwa. Co więcej, Chudy stworzył ciekawą koncepcję, że każdy z nas jest w pewien sposób niepełnosprawny. „Jesteśmy okaleczeni wszyscy, wszyscy bowiem jesteśmy narażeni na niedoskonałość i to bez względu czy jesteśmy niepełnosprawni czy nie. (...) Wszyscy niesiemy za sobą pewnego rodzaju brakowość: ci, którzy są niepełnosprawni i ci, którzy są zdrowi

17 Za: W. Szulc, Nauczanie sztuki i arteterapia, [w:] D. Janowski (red.), Edukacja kulturalna i aktywność artystyczna, Poznań 1996., s. 74.

18 W. Szulc, Kulturoterapia w Związku Radzieckim, „Kultura i Oświata” 1988, nr 4, s. 30 .

${ }^{19}$ A. Szudra, Etyczne aspekty sztuki osób niepetnosprawnych, [w:] P. Francuz, W. Otrębski (red.), Studia z psychologii w KUL, t. 15, Lublin 2008. 
Wiktoria Kabat - Nauczanie przez sztukę...

też są jakoś niepełnosprawni. W tym sensie niepełnosprawność jest naszą cechą istotną i nieodłączną, z którą się urodziliśmy, i z którą dotrzemy do końca"20. Jest to zupełnie inne od powszechnie znanej definicji niepełnosprawności. „Niepełnosprawnymi są osoby, których stan fizyczny, psychiczny lub umysłowy trwale lub okresowo utrudnia, ogranicza bądź uniemożliwia wypełnianie ról społecznych (...)”21. Warto spojrzeć na problem niepełnosprawności z różnych perspektyw, nie ograniczać się do książkowej definicji.

Osoby niepełnosprawne narażone są na negatywne bodźce z zewnątrz, które często wynikają z niewiedzy czy ignorancji otoczenia, które skłonne jest do zaniżania możliwości rozwojowych tych ludzi. Sprzyja to izolowaniu osób w jakiś sposób ograniczonych umysłowo od otoczenia ${ }^{22}$. W takich sytuacjach to właśnie sztuka pomaga zatrzymać się na chwilę, porozumieć ze środowiskiem, wyjaśnić bez pomocy słów wszystkie pragnienia, lęki czy przemyślenia. Jest to możliwość wyrażenia swojej własnej aktywności, która jest znaczącym warunkiem do rozwoju jednostki.

Również zaangażowanie społeczno-kulturowe, które można realizować dzięki twórczej aktywności pomaga uporać się z monotonią życia. Oprócz znudzenia gorsza jest apatia czy depresja, która wynika z niezrozumienia otoczenia ${ }^{23}$. Otoczenie dziecka wpływa na jego kreatywny rozwój od najmłodszych lat, co wielokrotnie zostało podkreślone w niniejszej pracy. Czynniki te dzielą się na endogenne, czyli osobowościowe (wewnętrzne) i egzogenne, to jest społeczno-kulturowe (zewnętrzne) ${ }^{24}$.

20 Ibidem.

21 Dz. U. 2008, nr 14, poz. 92.

${ }^{22}$ L. Bakier, Z. Stelter, Wspomaganie rozwoju osób niepetnosprawnych intelektualnie, [w:] A. Brzezińska, R. Kaczan, K. Smoczyńska (red.), Diagnoza potrzeb i modele pomocy dla osób z ograniczeniami sprawności, Warszawa 2010.

${ }^{23}$ W. Dykcik, Aktywność w kulturze i sztuce podstawq edukacji i twórczego życia osób niepełnosprawnych, [w:] E. Jutrzny (red.), Sztuka w życiu i edukacji osób niepełnosprawnych, Wydawnictwo Akademii Pedagogiki Specjalnej, Warszawa 2003, s. 9.

24 A. Brzezińska, Dzieciństwo z perspektywy cyklu życia człowieka, [w:] D. KornasBiela (red.), Oblicza dzieciństwa, Lublin 2001, s. 255. 
Od kilkunastu lat badacze obserwują spadek odpowiedniego dostosowania zachowania do sytuacji przez dzieci, co spowodowane jest szybkim postępem technologicznym, informatyzacją i globalizacją 25. To zjawisko prowadzi do zaniku kontaktów międzyludzkich, które są niezbędne do prawidłowego funkcjonowania. Termin izolacja zaczyna odnosić się ogólnie do dzieci, grup rówieśniczych, które coraz chętniej „znikają” w wirtualnej rzeczywistości. Wyróżnia się tu szczególnie nieumiejętność wyrażania złości, prowadzenia rozmowy, ograniczona asertywność, co może powodować późniejsze problemy emocjonal$n e^{26}$.

\section{Wychowanie w duchu twórczych postaw}

Terapeuci, pedagodzy, rodzice chcą pomóc dzieciom wyrazić swoje uczucia i edukować ich jak prawidłowo funkcjonować w społeczeństwie. Forma terapii przez działania twórcze stała się pociągającą perspektywą. Jest to jedna z dominujących koncepcji, druga skupia się na stosunku człowieka do sztuki, czyli tak zwanym „wychowaniu do sztuki"27.

Każdy wspierający opiekun powinien pamiętać o kilku zachowaniach, którymi jest zobowiązany kierować się, aby pobudzać twórczą aktywność dziecka. Te wytyczne można zastosować do osób zdrowych, jak i dotkniętych niepełnosprawnością intelektualną. Warunki jakie powinien spełniać dobry pedagog to przede wszystkim zrozumienie indywidualnych potrzeb swojego wychowanka, ciągłe pobudzanie wyobraźni przez różnorodne działania twórcze, czyli wykorzystywanie $\mathrm{w}$ swoich zajęciach także tych nietypowych materiałów, jakimi są - fotografia, collage, instalacja, rzeźba - czy pozwolenie na wybrudzenie się (malowanie spontaniczne czy malowanie dziesięcioma palcami). Praca czy też terapia grupowa stosowana jako metoda

\footnotetext{
25 J. Konieczna, Arteterapia w teorii i praktyce, Impuls, Kraków 2003, s. 9.

26 Z. Tyszka, Rodzina we współczesnym świecie, Poznań 2002.

27 W. Dykcik, Aktywność w kulturze..., op. cit., s. 13.
} 
Wiktoria Kabat - Nauczanie przez sztukę...

rozwoju to możliwość, dzięki której dziecko ma ułatwioną drogę do wyjścia z tak zwanej pułapki wykluczenia.

Szukanie inspiracji w otaczającym nas świecie, jak chociażby korzystanie z dorobku natury (liście, kasztany, piasek) - land art, zjawisko dość nowe w kontekście arteterapii, zaistniało pod koniec XX wieku. W sztuce pojawiło się w latach 60 . a największy rozwój miało miejsce dziesięć lat później28. Samo rozpatrywanie tematu, jakim jest sztuka ziemi, to połączenie różnych faktów, takich jak sytuacja polityczna, czyli wojna $\mathrm{w}$ Wietnamie czy tendencje w sztuce tamtego okresu - pop-art, minimal art, konceptualizm. Zjawisko to łączy zainteresowania społeczne, ekologiczne i artystyczne. Zasługuje na uwagę z powodu korzystnego wpływu przyrody na rozwój jednostek i tego, że często stanowi inspirację dla twórczości artystycznej. Zwolennicy nurtu ekopsychologii podkreślają, że to ewolucja sprawiła, że naszym naturalnym środowiskiem stała się natura ${ }^{29}$. Niektórzy twórcy przeciwstawiali się wystawianiu swoich prac w muzeach, co zresztą byłoby kłopotliwe, bo ich dzieła obejmowały wielkie płaszczyzny pól czy wtapiały się w otoczenie. To dość symboliczne w odniesieniu do twórczości osób niepełnosprawnych, które często chcą wyzwolić się i osiągnąć niezależność: w życiu czy w swojej aktywności twórczej.

Także pokazywanie pozytywnych postaw własnym zachowaniem to czynnik, który buduje autorytet i zaufanie, więc ważne jest, żeby pamiętać o dobrym nastawieniu do swoich podopiecznych czy dzieci. Szacunek powinien objawiać się nie tylko dla kompletnego dzieła, ale dla całego procesu ${ }^{30}$. Dla dzieci przebieg ten kończy się wraz z prezentacją efektów swojej pracy w szkole i w domu ${ }^{31}$. To nietradycyjne podejście, w którym podkreśla się edukacyjny i rozwojowo ubogacający wymiar samego obcowania ze sztuką. Edukacja kulturalna sprzyja wychowaniu w duchu optymizmu. Jest to bardzo potrzebne osobom,

${ }^{28}$ W. Karolak, Arteterapie. Język wizualny w terapiach twórczości i sztuce, Warszawa 2014 , s. 233.

${ }^{29}$ M. Gomes, A. D. Kanner, T. Roszak, Ecopsychology, San Francisco 1995.

${ }^{30}$ A. Kołodziejczyk, E. Czemierowska, Spójrz inaczej, Kraków 1993.

31 Program zajęć wychowawczo-profilaktycznych „Spójrz inaczej”. 
które dotknęły różnego rodzaju niepełnosprawności, a czas wolny staje się smutną koniecznością.

Przywoływani w pracy teoretycy i praktycy zgodnie twierdzą, że nauczanie przez sztukę to jedna $\mathrm{z}$ bazowych metod wychowawczych i może korzystnie wpływać na rozwój pozytywnych wzorców postępowań u młodych ludzi. Warto pamiętać, że początkowo wykorzystywano elementy ze świata sztuki do diagnozowania pacjentów, ponieważ wytwarzane kreacje ujawniały ich stany emocjonalne. Korzystano z tego głównie w psychoterapii i psychiatrii, lecz z biegiem czasu zaczęto doceniać także jej rozwojową funkcję 32 .

W 1995 roku B. Aumer podzieliła się swoimi spostrzeżeniami, gdy pracowała z osobami z głębszym upośledzeniem umysłowym: „(...) Wszyscy malowali w skupieniu. Zdumiała mnie doskonałość powstających obrazów. Wiele wskazywało na to, że osoby z góry wiedziały co i jak chcą namalować. Powstały dzieła pełne harmonii, wyszukane w kolorze, trafne kompozycyjnie, ciekawie rozwiązane rytmicznie. Spotkałam się z nieoczekiwaną eksplozją talentów. (...) Ci artyści dotknięci upośledzeniem umysłowym są ciekawsi od wielu artystów intelektualistów, są prostolinijni i artystycznie mądrzy"33. Jest to niepodważalny dowód na to, że kontakt ze sztuką to istotny czynnik autorehabilitacyjny dla osób $\mathrm{z}$ niepełnosprawnością intelektualną. Spontaniczność gestu tworzy prawdziwą wypowiedź, pozwala na rozmowę z samym sobą i wzmacnianie procesów poznawczych, co w rezultacie sprzyja osiągnięciu radości. Formy plastyczne czy malarskie istnieją w dorobku historii sztuki, przenikając do kultury popularnej.

Warto pamiętać, że każda osoba ma prawo być traktowana jako niezależna, autonomiczna jednostka, o czym często zapomina się w stosunku do osób borykających się z niepełnosprawnością intelektualną. Możliwość decydowania o swoim losie powinna być przywilejem nie tylko osób pełnosprawnych, ponieważ stanowi to podstawo-

32 S. Masgutowa, Psychoterapia przez sztukę, „Forum Psychologiczne” 1997, t. II, nr 1, s. 70.

33 B. Aumer, Sztuka jest jedna. Twórczość niepełnosprawnych, Warszawa 1995, s. 4. 
Wiktoria Kabat - Nauczanie przez sztukę...

wy element dla rozwoju człowieka ${ }^{34}$. Dla ludzi dotkniętych niepełnosprawnością i ograniczeniami umysłowymi poczucie samostanowienia to często kwestia bardzo istotna z powodu postrzegania ich jako wieczne dzieci. Tym samym, ważne jest aby rehabilitacja nie opierała się jedynie na przygotowywaniu do bycia biernym i ulegle grzecznym, lecz aktywnym w sferze społecznej i osobistej. Często dzieci i dorośli z niepełnosprawnością intelektualną „zamykają się” w znanym sobie otoczeniu, w którym czują się bezpiecznie, lecz wyjście poza własną sferę komfortu może stać się źródłem satysfakcji i wzmocnieni poczucia pewności siebie i atrakcyjności.

W kontekście działalności twórczej osób o zmniejszonej sprawności intelektualnej prawdopodobnie najbardziej koniecznym elementem jest zainteresowanie środowiska tego typu aktywnościami. Wsparcie, czynna pomoc i świadomość opiekunów i terapeutów także są nieodzowne. Tego typu inicjatywa powstała we współpracy partnerów z Polski, Włoch i Austrii w 2015 roku, gdy artyści niepełnosprawni pokazali swoje dzieła razem z twórcami - profesjonalistami. „Bezkresy wyobraźni" to wystawa, która odbyła się w bolońskiej Pinakotece Narodowej, toruńskim Centrum Sztuki Współczesnej „Znaki Czasu”, bydgoskiej Wyższej Szkole Gospodarki i austriackim Pregarten. Głównym kryterium doboru prac były, jak zaznaczała włoska koordynatorka projektu, Chiara Bellardi, walory artystyczne. Celem wystawy stało się pokazanie, że sztuka przełamuje wszelkie bariery. Wystawa prezentowała olbrzymią różnorodność zainteresowań, doboru barw, faktur. Na wernisażu pojawili się artyści niepełnosprawni z Pracowni Rozwijania Twórczości Osób Niepełnosprawnych (PRTON), działającej w ramach Środowiskowego Domu Samopomocy 35 .

Człowiek wykorzystuje wiele części poznawczych, w których emocje są integralną częścią. Czasami stają się pobudką do stworzenia

34 B. Tylewska-Nowak, Autonomia osób z głębszą niepełnosprawnościa intelektualnq w opinii wybranych grup społecznych, Poznań 2001.

35 Informacje pochodzą ze strony internetowej Centrum Sztuki Współczesnej: http://csw.torun.pl. 
dzieła, a niekiedy domykają proces twórczy. Niezależnie od inicjatyw powstania tych kompozycji należy przyjąć, że były formą wydobycia wewnętrznych odczuć. Upust jaki dajemy naszym emocjom wpływa na kreowanie się ekspresji. Według Pielasińskiej ekspresja jest „potwierdzeniem własnej autentyczności, a jednocześnie pozwala przekraczać granice własnej odrębności przez nawiązywanie związku ze światem"36. Krawiecka podkreśla, że plastyka jest narzędziem uniwersalnym, do którego mogą sięgać wszyscy i podzielić się z innymi wynikami swojej pracy ${ }^{37}$. Dobrą formą działań i stymulowania umysłu jest arteterapia, której szerokie możliwości i różnorodność mogą pobudzać aktywność umysłu. Jest to forma, która wpływa relaksacyjne i korzystnie oddziałuje na samopoczucie danej osoby ${ }^{38}$. Wspomniane działania plastyczne to jedna z metod arteterepeutycznych, którą skutecznie można odnosić do osób z niepełnosprawnością intelektualną, ponieważ znacznie buduje odrębność jednostki i stymuluje rozwój spontaniczności. Często też jest to jedyna droga porozumienia się ze światem, wydobycia swoich wewnętrznie skrywanych uczuć. Dla dzieci działania plastyczne są interesujące przez ruch związany z samym procesem. Analizowanie prac plastycznych daje terapeutom możliwość do odnajdywania informacji na temat poglądów, emocji, procesów myślowych, a nawet nastroju i wiedzy ich autorów. Mimo tego, więcej badań skupia się na obserwacji kreatywności niż na procesie powstania i okolicznościom im towarzyszącym, co zresztą podkreślał współczesny prekursor terapii przez sztukę, Adrian Hill ${ }^{39}$. Angażowanie do działań plastycznych może pobudzać do budowania twórczej postawy dziecka, która być może zaowocuje w przyszłości kreatyw-

${ }^{36}$ W. Pielasińska, Ekspresja jako wartość i potrzeba, Warszawa 1983, s. 54.

37 K. Krawiecka, Rysunek osób z niepetnosprawnościq intelektualnq - twórcze medium i fundament autorehabilitacji, „Annales Universitatis Mariae Curie-Skłodowska. Paedagogia-Psychologia" 2014, t. XXVI.

38 Z. Konieczyńska, Arteterapia i psychorysunek w praktyce klinicznej, [w:] L. Hanek, M. Pasella (red.), Arteterapia a proces leczenia i postępowania psychokorekcyjnego. Arteterapia, cz. III, „Zeszyty Naukowe Akademii Muzycznej we Wrocławiu” 1990, Nr 57, s. 118.

${ }^{39}$ A. Pikała, M. Sasin, Arteterapia. Scenariusze zajęć, Łódź 2016, s. 16. 
Wiktoria Kabat - Nauczanie przez sztukę...

nym podejściem do życia. Odwracanie uwagi od choroby przez sztukę to forma terapii, którą Hill zastosował u pacjentów - gruźlików. Pomysł zrodził się, gdy sam w czasie rekonwalescencji starał się nie myśleć o cierpieniu dzięki malowaniu.

\section{Twórczość dzieci}

Rysunki dziecięce określa się często jako bazgroły, które dają przyjemność przez ruch jaki stwarzają. Dzieci około drugiego roku życia powinny mieć jak najwięcej okazji do nieskrępowanej bazgroty, ponieważ ten czas oddziałuje na późniejsze umiejętności. Maluch, który chętnie sięga po kredki wyrabia w sobie nawyk chwytu, musi poza tym regulować naciski mięśniowe, tym samym gimnastykuje dłonie i palce. Dodatkowo, pracuje nad koordynacją wzrokowo-ruchową. Rysunek ma pobudzać do swobodnego przepływu myśli przez zarys linii, kolorowych barw, różnych form. Swobodny przepływ ekspresji jest widoczny zwłaszcza w wieku przedszkolnym, od około 3 do 6/7 lat. Końcowa faza tych działań to już jakaś konstrukcja, wypowiedź. Dzieci we wczesnym okresie szkolnym (7-12 lat) przywiązują dużą wagę do tworzonych przez siebie rysunków - angażują się, także na płaszczyźnie emocjonalnej, nadając narrację swoim wypowiedziom. Rozet w latach 60. zaprezentował wyniki badań eksperymentalnych, z których wynika, że 90\% dzieci w wieku pięciu lat wykazuje tendencje twórcze, dzieci siedmioletnie to już jedynie $10 \%$, u jednostek w wieku czterdziestu pięciu lat wynik oscylował wokół $2 \%$. Jednocześnie inne badania ${ }^{40}$ pokazały, że starsza młodzież przejawiała lepsze rezultaty niż młodsi koledzy, co tłumaczone zostało „kryzysem rozwoju zdolności dzieci w wieku 9-14". Inny badacz, Popek, również zaakcentował, że $\mathrm{w}$ dzieci po jedenastym roku życia tracą tendencje do działań spontanicznych ${ }^{41}$. Obserwacja twórczości dziecka może uwidaczniać

40 W. Limont, Analiza wybranych mechanizmów wyobraźni i twórczości. Badania eksperymentalne, Toruń 1994.

41 S. Popek. Aktywność twórcza dzieci i młodzieży, Warszawa 1988. 
nieprawidłowości w rozwoju dziecka. Pomaga także dziecku zrozumieć własne możliwości i dokonywać wyborów przez zapełnianie kartki ${ }^{42}$.

Spadek tych aktywności wraz z wiekiem często przypisuje się niewłaściwym metodom wychowawczym rodziców czy nauczycieli. Powodem jest chęć, żeby dzieci w szkole były przede wszystkim „grzeczne", co często oznacza, że powinny zachowywać się zgodnie z utartymi normami, według wskazań nauczycieli. Pedagodzy często nie rozumieją, że należałoby stworzyć warunki, które sprzyjają odnajdowaniu nietypowych rozwiązań - dzieci często boją się ryzyka związanego ze złamaniem utartych, znanych i akceptowanych przekonań, a nawet obawiają się rywalizacji z rówieśnikami ${ }^{43}$. Amerykański architekt, konstruktor, prekursor technologii hi-tech, Buckminster Fuller, sformułował myśl, że: „Wszystkie dzieci rodzą się geniuszami, a my przez pierwsze sześć lat życia pozbawiamy je tego geniuszu". Potwierdził to także Morris Stein, mówiąc, że „Społeczeństwa pełne «nie wolno», «nie powinno się», «nie trzeba» ograniczają wolność zadawania pytań i autonomię"44. Zniechęca to do poznawania świata, co więcej - może utrudnić późniejsze funkcjonowanie. Zapalnikiem dla kreatywności jest wyobraźnia, którą bezspornie przypisuje się dzieciom. Za negatywny przykład można przyjąć punktowy system oceniania w szkołach zachowania uczniów, ponieważ taki model utrwala u dzieci postawy roszczeniowe i nastawione na zysk. Dziecko zastanawia się, co musi zrobić i komu pokazać, żeby uzyskać lepszą ocenę. Działa według utartych schematów, dodatkowo zatraca przy tym bezinteresowność. Paradoksalnie, głos dzieci na temat ich własnej edukacji często jest bagatelizowany, co także sprawia, że nie mają oni szansy na twórczą modulację swojej własnej edukacji.

42 M. Posłuszna-Owczarz, Niepetnosprawność a rysunek, [w:] Z. Tarkowski, G. Jarzębowska (red.), Człowiek wobec ograniczeń: niepełnosprawność, komunikowanie, diagnoza, terapia, Lublin 2002, s. 276.

${ }^{43}$ H. Krauze-Sikorska, Edukacja przez sztukę: o edukacyjnych wartościach artystycznej twórczości dziecka, Poznań 2006.

44 M. Stein, Creativity and culture, „Journal of Psychology” 1953, v. 36, s. 313. 
Wiktoria Kabat - Nauczanie przez sztukę...

Wygrzebywanie pomysłów z odmętów wyobraźni może prowadzić do powstawania rzeczy nowych, wcześniej nieznanych. Stwierdzenie nawiązuje nie tylko do sztuki, ale też odnosi się do wypracowywania w sobie samym nowych granic. Dzięki twórczości człowiek kreuje rzeczywistość, która wiążę się z potrzebą przeżywania nowych doświadczeń. Ryzyko tworzenia i stwarzania innych realiów zaspokaja człowieczą chęć do przeżywania przygód 45 .

Osoby z niepełnosprawnością często czują się niezdolne do jakichkolwiek aktywności przez swoje ograniczenia, równoważąc swoje upośledzenie z byciem bezużytecznym. Gdy nie zyskują przychylności środowiska od dzieciństwa, w dorosłym życiu tym bardziej jest im trudno uwierzyć w sens swoich działań. Choć może zabrzmi to brutalnie, nie czują się do końca pełnoprawnymi ludźmi (także przez nieprzychylność i odtrącenie otoczenia), więc nie wydaje im się by byli skłonni być artystami. Boją się oceny przez pryzmat swojej niepełnosprawności, co prowadzi o działań jedynie nieprofesjonalnych i nazywanych kolokwialnie „do szuflady”. Jak mówi S. Szuman: „Artyści to ludzie, którzy wiele przeżyli, którzy przez swoje dzieła przekazują własne emocje innym, i którzy - wreszcie - trafiają do serc"46. Jeśli kierować się tą definicją, wiele osób niepełnosprawnych, które podejmują działalność artystyczną ma prawo określać się mianem artysty.

\section{Postawa twórcza a niepełnosprawność}

Należałoby zastanowić się także czym tak naprawdę charakteryzuje się postawa twórcza, która wywodzi się ze specyficznych funkcji psychicznych ${ }^{47}$. Warto zacząć od tego, że trudno jednoznacznie zdefiniować to pojęcie, gdyż samo w sobie wykazuje sprzeczność - „postawa" rozumiana jako światopogląd to forma z gruntu stała, stabilna.

\footnotetext{
${ }^{45}$ H. Krauze-Sikorska, Edukacja przez sztukę..., op. cit., s. 41.

${ }^{46} \mathrm{~J}$. Kierenko, Między rehabilitacjq̨ a działalnościq twórczq osób niepełnosprawnych, [w:] M. Kuśpit (red.), Barwy twórczości, Lublin 2013, s. 193.

${ }^{47} \mathrm{E}$. Włodek, Twórczość a inteligencja, http://www.sosw.bochnia.pl/podstrony/ publikacje/5w.pdf (dostęp: 5.01.2017).
} 
Wielu teoretyków w obrębie nauk psychologicznych i pedagogiki ma odmienne zdanie co do rozumienia terminu „twórczość”, co oznacza, że niektórzy (jak wspomniany poniżej Pietrasiński) skupiają się na społecznej innowacji wytworu, a inni na indywidualnym rozwoju jednostki przez własne zabiegi48. Pole jest na tyle szerokie i wielowymiarowe, że nie powinno się kojarzyć twórczości artystycznej jedynie z postacią twórcy, a stawiać obok wielkich dzieł na przykład prace małego dziecka. Najtrafniejsza w mojej opinii jest definicja zaproponowana przez Ericha Fromma. Pisał, że: „Twórczość jako postawa jest warunkiem każdej twórczości w sensie tworzenia czegoś nowego, ale może ona istnieć nawet wówczas, gdy nowość nie powstaje" 49 . W kontekście działań młodych osób trzeba podkreślić, że ważna jest wspomniana „nowość” dla dziecka sama w sobie, nie w sensie społecznego wynalazku. Zaznacza to Gołaszewska ${ }^{50}$, podkreślając oddziaływanie tworu na psychikę twórcy, jego ubogacenie dzięki nabywaniu doświadczeń. Istotniejszym czynnikiem jest zwrócenie uwagi na proces i reakcje emocjonalne, gdzie oczywiście przyjmuje się możliwe późniejsze sukcesy.

Edward Nęcka rozróżnia dwa stosunki podejścia do twórczości: elitarne i egalitarne ${ }^{51}$. Zwolennicy podejścia elitarnego uważają, że o twórczości można wspominać tylko w kontekście wybitnych jednostek, co jednak uważam za bardzo ograniczoną postawę, gdyż trzeba każdemu pozwolić na samorozwój, który może być właśnie początkiem dla nieodkrytego wcześniej talentu. Zwolennicy podejścia egalitarnego zaznaczają, że każdy wykazuje zdolności twórcze w mniejszym lub większym stopniu, jednak do pobudzania tej aktywności u dzieci potrzeba dużej ekspresyjności52. W XX wieku pojawiła się

48 H. Krauze-Sikorska, Edukacja przez sztukę..., op. cit., s. 23.

${ }^{49}$ E. Fromm, Creative attitude, [in:] H. H. Anderson (ed.:), Creativity and its cultivation, Harper, New York 1959, s. 44.

50 M. Gołaszewska, Twórczość i osobowość twórcy, Warszawa 1958, s. 26.

${ }^{51}$ E. Nęcka, Psychologia twórczości, Gdańsk 2001.

52 A. Minczanowska, Kreatywność jako wartość i cel edukacji, [w:] E. Zwolińska (red.), Edukacja kreatywna, Bydgoszcz 2005. 
Wiktoria Kabat - Nauczanie przez sztukę...

teoria pankreacjonizmu, która głosi, że każde działanie człowieka można uważać za twórcze, jeśli tylko wykracza poza proste naśladownictwo. Ogół refleksji nad światem i właściwie każda aktywność może być twórcza, pod warunkiem, że człowiek wnosi coś od siebie. Ta myśl została wyjaśniona przez Tatarkiewicza w „Dziejach sześciu pojęć” 53. Nęcka wyodrębnił dodatkowo cztery poziomy twórczości. Najniższy z nich nazywa płynnym, który jest koniecznym oparciem dla dalszych stopni działalności twórczej. Tworzy go ciekawość poznawcza, dzięki której jesteśmy zdolni do kreowania pomysłów. Na tym etapie nie myśli się jeszcze o wybitnych, nowatorskich rozwiązaniach, czy dziełach, ale są to stymulanty, które mogą rozwijać się, gdy zaistnieją pewne istotne elementy jak chociażby otwartość jednostki, która ułatwia dalszy proces. Kitowska-Łysiak, pedagog ze Specjalnego Ośrodka Szkolno-Wychowawczego w Bochni w artykule „Twórczość a inteligencja" formułuje myśl, że osoby z niepełnosprawnością umysłową posiadają zdolności do wykazywania jej, ponieważ jest to cecha każdego człowieka, tylko rozwinięta w mniejszym lub większym stopniu ${ }^{54}$. Limont dodatkowo zawęża rozumienie pojęcia do określenia twórczości płynnej jako „funkcjonowanie kreatywne" 55. Kolejny etap to twórczość skrystalizowana, do której wykonywania potrzeba już konkretnej wiedzy i doświadczenia. Później mamy do czynienia z twórczością dojrzałą, która zostaje poddana społecznej ocenie i twórczością wybitną, zmieniającą dorobek ludzkości56.

Działanie twórcze można rozumieć jako postępowanie, którego wyniki są nowatorskie, przesiąknięte pomysłowymi rozwiązaniami co do efektów lub użytych narzędzi ${ }^{57}$. Niektórzy uważają, że pojęcie kreatywność i twórczość to synonimy, lecz kreatywność dotyczy w więk-

53 W. Tatarkiewicz, Dzieje sześciu pojęć. Piękno. Forma. Twórczość. Odtwórczość. Przeżycie estetyczne, Kraków 1982

${ }^{54}$ M. Kitowska-Łysiak, Nikifor, http://culture.pl/pl/tworca/nikifor (dostęp: 29.12. 2016).

55 W. Limont, Twórczość w aspekcie cyklu życia, [w:] E. Dombrowska, A. Niedźwiecka (opr.), Twórczość - wyzwanie XXI wieku, Kraków 2003, s. 19.

56 E. Nęcka, Psychologia twórczości, Gdańsk 2001.

57 Z. Pietrasiński, Myślenie twórcze, Warszawa 1969. 
szym stopniu działań nastawionych na samorealizację ${ }^{58}$. Osoba kreatywna, według ujęcia badawczego, łączy w sobie wiele umiejętności. Kreatywność jest swojego rodzaju potencjałem, często określeniem usposobienia człowieka. Świat dzieli się na ludzi mniej lub bardziej pomysłowych, co oznacza, że ta cecha jest traktowana jako stała ${ }^{59}$. Osoba traktowana jako kreatywna potrafi posługiwać się ideami, czyli wykorzystywać także własne doświadczenia i odnajdywać się w różnych rolach. Żywo kierować obrazami wytworzonymi przez wyobraźnię. Dodatkowo, powinna być elastyczna w obrębie myślenia abstrakcyjnego, umieć operować wspomnieniami, pojęciami, spostrzeżeniami, co oznacza także umiejętność skupienia uwagi, przekonaniami, intencjami ${ }^{60}$. Ważny jest otwarty umysł, skory do podejmowania wyzwań. Otwartość to gotowość na przyjmowanie nowych doświadczeń61. Otwarty umysł pomaga odnaleźć się we współczesnym świecie, dzięki połączeniu czterech czynników: umiejętności zauważania, przeżywania, uczenia się i postawę twórczą ${ }^{62}$.

Na kształtowanie się postawy twórczej ma wpływ środowisko w relacji z cechami osobowymi jednostki63, a także motywacja. Jeśli wytworzy się korzystne warunki dla osoby z niepełnosprawnością intelektualną, to ona także będzie wykazywała predyspozycje do postaw twórczych ${ }^{64}$. Spontaniczna aktywność małego dziecka (także z niepełnosprawnością intelektualną) w tym kierunku powinna być znakiem dla rodzica ${ }^{65}$, aby podtrzymywać i inicjować jego zaintereso-

58 W. Limont, Twórczość w aspekcie cyklu życia, op. cit.

${ }^{59}$ M. Karwowski, Kreatywność, twórczość, czy permanentna transgresja? Uwagi o aktywności osób niepełnosprawnych intelektualnie z perspektywy psychologii twórczości, [w:] J. Głodkowska, A. Giryński (red.), Kreatywność osób z niepełnosprawnościq intelektualnq - czy umiemy myśleć inaczej?, Kraków 2009, s. 14.

${ }^{60}$ E. Zwolińska (red.), Edukacja kreatywna, Bydgoszcz 2005, s. 57.

61 M. Kaczyńska-Grzywak, Trudy rozwoju, Warszawa 1988.

62 M. Boruch, Wychowanie przez sztukę w ujęciu Ireny Wojnar, [w:] Człowiek w kulturze, Lublin 2014, s. 229-237.

63 Por. E. Nęcka, Proces twórczy i jego ograniczenia, Kraków 1999.

64 R. Glotton, C. Clero, Twórcza aktywność dziecka, Warszawa 1985, s. 49

$65 \mathrm{H}$. Olechnowicz, Wyzwalanie aktywności dzieci głębiej upośledzonych umysłowo, Warszawa 1994, s. 325. 
Wiktoria Kabat - Nauczanie przez sztukę...

wanie. Małe dzieci tak jak i często osoby z ograniczeniem intelektualnym nie znają dorobku kulturowego, bazują na własnej intuicji, wzorcach i schematach, z których może wyłonić się atrakcyjna, niespotykana wcześniej kompozycja. Radość z tworzenia może inicjować późniejszą kreatywność66.

Przypuszczalnie, trudne sytuacje rodzinne czy traumatyczne wspomnienia mogą być zapalnikiem do wzmożonej, twórczej aktywności, co oczywiście nie jest warunkiem koniecznym. Dopatruje się na tej płaszczyźnie podwyższonej chęci tworzenia jako ucieczki od niesprzyjającego środowiska czy też większej wrażliwości emocjonalnej przez przykre ślady z przeszłości ${ }^{67}$. Zgodnie $\mathrm{z}$ tą hipotezą, osoby niepełnosprawne, które są bardziej narażone na negatywne reakcje środowiska, borykające się z niezrozumieniem otoczenia mogą wykazywać większe chęci do podejmowania twórczej aktywności. Jest to oczywiście potencjalne założenie. Z drugiej strony mówi się ${ }^{68}$, że twórczość najlepiej rozwija się $\mathrm{w}$ atmosferze zrozumienia, bezpieczeństwa i wsparcia. Ciekawe - z punktu widzenia socjologicznego - są badania Nalaskowskiego (1989/1998), z których wynikają dwa zaskakujące wnioski. Pierwszy z nich odnosi się do specyficznego, ale pozytywnie oddziałującego na twórczy rozwój klimatu, panującego w małych miejscowościach (tak zwane otuliny małego miasta). Drugi dotyczy wykształcenia matki, które w rodzinach najbardziej twórczych jest wyższe od kwalifikacji ojca69.

Coraz częściej podkreśla się, że rola inteligencji w procesie twórczym nie jest aż tak istotna, co próbował udowodnić w swojej kontrowersyjnej tezie amerykański psycholog, Paul Torrance (1915-2003). Uważał on, że do wykazania postawy twórczej u człowieka potrzebne jest osiągnięcie granicznego progu inteligencji, który wynosi 110 jed-

66 W. J. J. Gordon Synectics: the development of creative capacity, New York 1961.

67 M. Zadłużny, Biograficzne konteksty formowania się postawy twórczej, „Dyskursy Młodych Andragogów" 2015, nr16, s. 233.

68 Por. M. Ziemska (red.), Rodzina i dziecko, Warszawa 1986.

${ }^{69}$ M. Karwowski, Klimat dla kreatywności. Koncepcje, metody, badania, Warszawa 2009, s. 20. 
nostek ilorazu. Co więcej, według wspomnianej hipotezy progu ${ }^{70}$, pozytywna relacja między twórczością a inteligencją istnieje jedynie w stosunku do osób o ilorazie inteligencji, który nie przekraczał 120 jednostek. Przykładem może być Nikifor Krynicki (wł. Epifaniusz Drowniak) uważany przez otoczenie za upośledzonego dziwaka. Malował prawdopodobnie od najmłodszych lat, choć początki jego kariery są niejasne. Motywacją Krynickiego była chęć stania się „Metajką z Krynicy", z której pochodził ${ }^{71}$. Uważany jest za jednego z najwybitniejszych prymitywistów, który doskonale operował barwą. Wydaje się, że osoby, które wykazują cechy sawantyzmu nie są twórcze, ale próbują w ten sposób skomunikować się ze światem, lecz z drugiej strony symbolika prac często jest na tyle odkrywcza, że niesie za sobą pewne znamiona nowości.

Ludzie o wyższym ilorazie inteligencji nie wykazywali zdolności do wytwarzania nowatorskich dzieł. Jednakże zdarzają się przypadki osób z niepełnosprawnością intelektualną o niskim poziomie IQ (4070)72. które wykazują zdolności - również artystyczne - zwane wyspowymi. Osoby takie określa się mianem sawantów (fr. savant uczony) i choć we współczesnym diagnozowaniu syndrom sawantyzmu nie jest oficjalnie uznawany, to odnotowuje się przypadki opisywania osób z zaburzeniami tego typu ${ }^{73}$. Tym mianem określa się jednostki, które na niektórych płaszczyznach wykazują się olbrzymim talentem i geniuszem, mimo że na innych polach nie potrafią sobie poradzić, nie są samodzielne. Syndrom ten najczęściej występuje u mężczyzn autystycznych, opóźnionych umysłowo. Istnieją rozbieżne założenia, czy sawantyzm może być nabyty ${ }^{74}$, czy jedynie wrodzony ${ }^{75}$.

${ }^{70}$ M. Karwowski, Konstelacje zdolności. Typy inteligencji a kreatywność, Kraków 2005.

${ }^{71}$ M. Kitowska-Łysiak, Nikifor, http://culture.pl/pl/tworca/nikifor (dostęp: 29.12. 2016).

${ }^{72} \mathrm{~K}$. Markiewicz, Twórczość jako sposób wypowiadania się osób z niepełnosprawnościq umysłową, [w:] M. Kuśpit (red.), Barwy twórczości, Lublin 2013.

73 Ibidem.

74 Zob.: B. Rimland, Savant capabilities of autistic children and their cognitive implications, [w:] G. Serban (red.), Cognitive defects in the development of mental illness, 
Wiktoria Kabat - Nauczanie przez sztukę...

Badania z 2007 roku (Preti, Vellante) wykazały, że te niezwykłe zdolności wiążą się z dominacją prawej półkuli mózgu.

Dla autorek podwalin teorii pedagogiki specjalnej, twórczość to istotny element rewalidacji, o czym pisała Maria Grzegorzewska76, czy Janina Doroszewska, która w swoim dziele „Pedagogika specjalna” 77 zaznaczała, że aktywny wkład dziecka z upośledzeniem umysłowym w nauczany materiał jest często znamiennym elementem jego rozwoju i pozwala mu na szybsze i sprawniejsze przyswajanie materiałów.

Nowatorskie badania Getzelsa i Jacksona ${ }^{78}$ przeprowadzone na początku lat 60. analizowały zdolności twórcze uczniów w porównaniu do ich inteligencji. Dzieci określone jako bardzo twórcze, które nie miały zbyt dużego poziomu inteligencji osiągały podobne wyniki w nauce do rówieśników bardzo inteligentnych, lecz słabo wypadających w testach kreatywności. Zauważono też, że dzieci „jedynie” inteligentne myślały o swojej przyszłości w konwencjonalny sposób, a te twórcze widziały siebie w roli wynalazcy czy podróżnika. Okazało się też, że dzieci twórcze cechują się większym poczuciem humoru. Choć badania zostały zakwestionowane z powodu niewłaściwie przygotowanego eksperymentu to stały się bodźcem dla wielu innych testów $\mathrm{z}$ tego zakresu.

Podsumowując, największe znaczenie dla rozwoju twórczości osób niepełnosprawnych wcale nie musi być talent. Jest to w dużej, jak nie największej mierze, pozytywne wzmocnienie ze strony środowiska oraz wyjście poza grupę innych osób niepełnosprawnych. Pokazanie siebie samego i swojej twórczości innym także może mieć wartość terapeutyczną. Skupiam się na twórczości dzieci, ponieważ to właśnie

New York 1978; Treffert D. A., Islands of genius: the bountiful mind of the autistic, acquired and sudden savant, London 2010.

75 M. E. Raichle, Two views of brain function, „Trends in Cognitive Sciences” 2010, $\mathrm{Nr} 14$ (4).

76 M. Grzegorzewska, Listy do młodego nauczyciela, Warszawa 1957.

77 J. Doroszewska, Pedagogika specjalna, t. I-II, Wrocław 1989. 2005.

78 Za: E. Nęcka, J. Orzechowski, A. Słabosz, B. Szymura, Trening twórczości, Gdańsk 
te najwcześniejsze budowanie postawy twórczej, zachęcanie do kontaktów ze sztuką może uwrażliwiać i budować pewność swoich działań u dorosłego.

\section{Bibliografia:}

Aumer B., Sztuka jest jedna. Twórczość niepetnosprawnych, WSiP, Warszawa 1995.

Bakier L., Stelter Z., Wspomaganie rozwoju osób niepełnosprawnych intelektualnie, [w:] A. Brzezińska, R. Kaczan, K. Smoczyńska (red.), Diagnoza potrzeb i modele pomocy dla osób z ograniczeniami sprawności, Warszawa 2010.

Boruch M., Wychowanie przez sztukę w ujęciu Ireny Wojnar, [w:] Człowiek w kulturze, Lublin 2014.

Brzezińska A., Dzieciństwo z perspektywy cyklu życia człowieka, [w:] D. Kornas-Biela (red.), Oblicza dzieciństwa, Lublin 2001, s. 255.

Doroszewska J., Pedagogika specjalna. Tom 1 - Podstawowe problemy teorii i praktyki, Zakład Narodowy im. Ossolińskich, Wrocław 1989.

Dykcik W., Aktywność w kulturze i sztuce podstawq edukacji i twórczego życia osób niepełnosprawnych, [w:] E. Jutrzny (red.), Sztuka w życiu i edukacji osób niepełnosprawnych, Wydawnictwo Akademii Pedagogiki Specjalnej, Warszawa 2003.

Fromm E., Creative attitude, [in:] H. H. Anderson (ed.:), Creativity and its cultivation, Harper, New York 1959.

Glotton R., Clero C., Twórcza aktywność dziecka, WSiP, Warszawa 1985.

Gładyszewska-Cylulko J., Arteterapia w pracy pedagoga. Teoretyczne i praktyczne podstawy terapii przez sztukę, Impuls, Kraków 2011.

Gołaszewska M., Twórczość i osobowość twórcy, Warszawa 1958.

Gomes M., Kanner A. D., Roszak T., Ecopsychology, San Francisco 1995.

Gordon W. J. J., Synectics: the development of creative capacity, Harper\&Row, New York 1961.

Gorgól A., Arteterapia w teorii i praktyce na podstawie warsztatów artystycznych dla osób niepełnosprawnych, [w:] A. Glińska-Lachowicz (red.), Arteterapia w nauce i praktyce. Teoria - rozwój - możliwości, Uniwersytet Opolski, Opole 2015. 
Wiktoria Kabat - Nauczanie przez sztukę...

Grudziewska E., Arteterapia jako forma pracy z dzieckiem z upośledzeniem umysłowym, „Szkoła Specjalna” 2010, Nr 3.

Grzegorzewska M., Listy do młodego nauczyciela, Warszawa 1957.

Handford O., Stachyra K. (red.), Terapia przez sztukę, Polskie Stowarzyszenie Terapii Przez Sztukę, Lublin 2012/2013.

Hanek L., Wprowadzenie do sesji na temat arteterapii, „Zeszyty Naukowe Akademii Muzycznej we Wrocławiu" 1989, Nr 48.

Kaczyńska-Grzywak M., Trudy rozwoju, Warszawa 1988.

Karczmarzyk M. A., Co znaczq̨ rysunki dziecięce?, ANVI, Gdańsk 2014.

Karolak W., Arteterapie. Język wizualny w terapiach twórczości i sztuce, Difin, Warszawa 2014.

Karp E., Wojciechowska K., Mielczarek M., Cieślak M., Aktywność twórcza dzieci i młodzieży, [w:] W. Dorbołowicz, M. Karwowski (red.), W stronę kreatywności, Wydawnictwo Akademii Pedagogiki Specjalnej, Warszawa 2002.

Karwowski M., Konstelacje zdolności. Typy inteligencji a kreatywność, Kraków 2005.

Karwowski M., Klimat dla kreatywności. Koncepcje, metody, badania, Difin, Warszawa 2009.

Karwowski M., Kreatywność, twórczość, czy permanentna transgresja? Uwagi o aktywności osób niepełnosprawnych intelektualnie z perspektywy psychologii twórczości, [w:] J. Głodkowska, A. Giryński (red.), Kreatywność osób z niepełnosprawnościq intelektualnq - czy umiemy myśleć inaczej?, Akapit, Kraków 2009.

Kierenko J., Między rehabilitacją a działalnością twórczq osób niepełnosprawnych, [w:] M. Kuśpit (red.), Barwy twórczości, Wyd. UMCS, Lublin 2013.

Kitowska-Łysiak M., Nikifor, http://culture.pl/pl/tworca/nikifor (dostęp: 29.12.2016).

Kochanowska E., Skibska J. (red.), Nauczyciel wobec wyzwań współczesności. Dylematy, poszukiwania, inspiracje, Wydawnictwo Naukowe Akademii Techniczno-Humanistycznej, Bielsko-Biała 2013.

Kołodziejczyk A., Czemierowska E., Spójrz inaczej, Kraków 1993.

Konieczna J., Arteterapia w teorii i praktyce, Impuls, Kraków 2003.

Konieczyńska Z., Arteterapia i psychorysunek w praktyce klinicznej, [w:] L. Hanek, M. Pasella (red.), Arteterapia a proces leczenia i postępowania psychokorekcyjnego. Arteterapia, cz. III, „Zeszyty Naukowe Akademii Muzycznej we Wrocławiu" 1990, Nr 57. 
Kosmala M., Ogrody zabaw dziecięcych szansq na harmonijny rozwój dziecka. Place zabaw - miejsce harmonijnego rozwoju, [w:] „Materiały seminaryjne VII Ogólnopolskiego Seminarium «Podwórka 2002»", Wrocław 2002.

Krauze-Sikorska H., Edukacja przez sztukę: o edukacyjnych wartościach artystycznej twórczości dziecka, Wydawnictwo Naukowe UAM, Poznań 2006.

Krawiecka K., Rysunek osób z niepetnosprawnościq intelektualnq - twórcze medium $i$ fundament autorehabilitacji, „Annales Universitatis Mariae Curie-Skłodowska. Paedagogia-Psychologia" 2014, t. XXVI.

Kwieciński Z., Śliwerski B. (red.), Podręcznik pedagogiczny, Warszawa 2006.

Limont W., Analiza wybranych mechanizmów wyobraźni i twórczości. Badania eksperymentalne, Wyd. UMK, Torun 1994.

Limont W., Twórczość w aspekcie cyklu życia, [w:] E. Dombrowska, A. Niedźwiecka (opr.), Twórczość - wyzwanie XXI wieku, Impuls, Kraków 2003.

Lizęga M., Rysunki dziecięce w kontekście powstawania wytworu, [w:] Z. Tarkowski, G. Jarzębowska (red.), Człowiek wobec ograniczeń: niepełnosprawność, komunikowanie, diagnoza, terapia, ORATOR, Lublin 2002.

Łoza B., Chmielnicka-Plaskota A. (red.), Arteterapia, cz. 1, Difin, Warszawa 2014.

Łoza B., Chmielnicka-Plaskota A. (red.), Arteterapia, cz. 2, Difin, Warszawa 2014.

Markiewicz K., Twórczość jako sposób wypowiadania się osób z niepełnosprawnościq umysłowa, [w:] M. Kuśpit (red.), Barwy twórczości, Wyd. UMCS, Lublin 2013.

Masgutowa, S., Psychoterapia przez sztukę, „Forum Psychologiczne” 1997, t. II, nr 1.

Minczanowska A., Kreatywność jako wartość i cel edukacji, [w:] E. Zwolińska (red.), Edukacja kreatywna, Wydawnictwo Akademii im. Kazimierza Wielkiego, Bydgoszcz 2005.

Nęcka E., Orzechowski J., Słabosz A., Szymura B., Trening twórczości, GWP, Gdańsk 2005.

Nęcka E., Proces twórczy i jego ograniczenia, Kraków 1999.

Nęcka E., Psychologia twórczości, Gdańskie Towarzystwo Psychologiczne, Gdańsk 2001.

Olechnowicz H., Wyzwalanie aktywności dzieci głębiej upośledzonych umysłowo, Warszawa 1994.

Pielasińska W., Ekspresja jako wartość i potrzeba, WSiP, Warszawa 1983. 
Wiktoria Kabat - Nauczanie przez sztukę...

Pietrasiński Z, Myślenie twórcze, Warszawa 1969.

Pikała A., Sasin M., Arteterapia. Scenariusze zajęć, Wydawnictwo Uniwersytetu Łódzkiego, Łódź 2016.

Popek S. Aktywność twórcza dzieci i młodzieży, WSiP, Warszawa 1988.

Posłuszna-Owczarz M., Niepełnosprawność a rysunek, [w:] Z. Tarkowski, G. Jarzębowska (red.), Człowiek wobec ograniczeń: niepełnosprawność, komunikowanie, diagnoza, terapia, ORATOR, Lublin 2002.

Raichle M. E., Two views of brain function, "Trends in Cognitive Sciences” 2010, Nr 14 (4).

Read H., Wychowanie przez sztukę, Ossolineum, Wrocław 1976.

Rimland B., Savant capabilities of autistic children and their cognitive implications, [w:] G. Serban (red.), Cognitive defects in the development of mental illness, Brunner/Mazel, New York 1978.

Rozet I., Psychologia fantazji, PWN, Warszawa 1982.

Skorny Z., Arteterapia a zaburzenia emocjonalne, [w:] L. Hanek, M. Pasella (red.), Teoretyczne podstawy arteterapii, „Zeszyty Naukowe Akademii Muzycznej we Wrocławiu", Wrocław 1989.

Stein M., Creativity and culture, „Journal of Psychology” 1953, v. 36.

Szafraniec G. (red.), Kultura a integracja - sztuka wobec niepełnosprawności, Katowice 2003.

Szudra A., Etyczne aspekty sztuki osób niepełnosprawnych, [w:] P. Francuz, W. Otrębski (red.), Studia z psychologii w KUL, t. 15, Lublin 2008.

Szulc W., Edukacja arteterapeutów na poziomie akademickim. Problem zawodu i modele kształcenia, [w:] A. Glińska-Lachowicz (red.), Arteterapia w nauce i praktyce. Teoria - rozwój - możliwości, Uniwersytet Opolski, Opole 2015.

Szulc W., Kulturoterapia w Związku Radzieckim, „Kultura i Oświata” 1988, nr 4.

Szulc W., Nauczanie sztuki i arteterapia, [w:] D. Janowski (red.), Edukacja kulturalna i aktywność artystyczna, Poznań 1996.

Szulc W., Sztuka w służbie medycyny: od antyku do postmodernizmu, Poznań 2001.

Szuman S., Sztuka dziecka, WSiP, Warszawa 1990.

Tarkowski Z., Jarzębowska G. (red.), Człowiek wobec ograniczeń: niepełnosprawność, komunikowanie, diagnoza, terapia, ORATOR, Lublin 2002.

Tatarkiewicz W., Definicja sztuki, [w:] P. Skubiszewski (red.), Wstęp do historii sztuki, Warszawa 1973. 
Tatarkiewicz W., Dzieje sześciu pojęć. Piękno. Forma. Twórczość. Odtwórczość. Przeżycie estetyczne, PWN, Kraków 1982.

Treffert D. A., Islands of genius: the bountiful mind of the autistic, acquired and sudden savant, Jessica Kingsley Publisher, London2010.

Tylewska-Nowak B., Autonomia osób z głębszq niepełnosprawnościq intelektualnq w opinii wybranych grup społecznych, Poznań 2001.

Tyszka Z., Rodzina we współczesnym świecie, Poznań 2002.

Tytko M., Wychowanie artystyczne dzieci i młodzieży a kultura plastyczna, [w:] A. Boguszewska, A. Mazur (red.) Wybrane problemy edukacji plastycznej dzieci i młodzieży, Lublin 2013.

Welsch W., Estetyka poza estetyką. O nowa postać estetyki, Universitas, Kraków 1995.

Włodek E., Terapeutyczne znaczenie aktywizacji osób niepełnosprawnych, [w:] B. Grochmal-Bach (red.), Pedagogiczna refleksja nad życiem i śmiercia, Wydawnictwo WAM, Kraków 2013.

Włodek E., Twórczość a inteligencja, http://www.sosw.bochnia.pl/podstro ny/publikacje/5w.pdf (dostęp: 5.01.2017).

Wojnar I., Estetyka i wychowanie, Warszawa 1970.

Zadłużny M., Biograficzne konteksty formowania się postawy twórczej, „Dyskursy Młodych Andragogów" 2015, nr 16, s. 233.

Ziemska M. (red.), Rodzina i dziecko, Warszawa 1986.

Zwolińska E. (red.), Edukacja kreatywna, Wydawnictwo Akademii im. Kazimierza Wielkiego, Bydgoszcz 2005.

\section{Netografia:}

Abramowicz M., Jestem osobq kreatywnq, https://lublin.eu/download/gfx/ lublin/userfiles/_public/mieszkancy/on_lublin/niepelnosprawni_w_lubli nie/wydawnictwa/vademecum/i.ii.i.3.7_jestem_osoba_kreatywna.pdf (dostęp: 10.01.2017).

Jankowska M., Wychowanie do twórczości, http://www.fidesetratio.org.pl/ files/plikipdf/jankowska1.pdf (dostęp: 30.12.2016).

Włodek E., Twórczość a inteligencja, http://www.sosw.bochnia.pl/podstro ny/publikacje/5w.pdf (dostęp: 5.01.2017).

Kitowska-Łysiak M., Nikifor, http://culture.pl/pl/tworca/nikifor (dostęp: 29.12.2016). 